\title{
Personal bank account access and awareness: An analysis of the technological and informational constraints of Australian consumers
}

\author{
Andrew C. Worthington \\ School of Accounting and Finance, University of Wollongong, NSW, Australia
}

\begin{abstract}
Logit models are used to predict access and awareness of personal bank accounts. Access is defined as the ability and willingness to use ATM, EFTPOS, telephone and internet banking. Awareness relates to the understanding of bank statements, fee and charges, account shopping around and internet calculators. Newer ways of accessing bank accounts are confined to young, urban, well-educated, white-collar occupations. Awareness is lower for respondents with less education, non-workers, farm workers, unskilled and renting households, and higher for white-collar occupations, couples and those with higher incomes and savings.
\end{abstract}

Keywords Transaction and savings accounts, banking fees and charges, telephone and internet banking.

\section{Introduction}

One of the defining features of personal banking in Australia in the last twenty years has been the proliferation in ways of accessing transaction and savings accounts. Starting in the 1980s with automated-teller (or banking) machines (ATM) and electronic funds transfer point of sale (EFTPOS) [where sales transactions (and sometimes cash withdrawals) are debited to the customer's bank account at the point of sale with a debit card], and more recently with telephone and internet banking, the trend has been, at least from the banks' perspective, from more-costly labour-intensive branch services to less-costly capital-intensive technological services, and from cash to non-cash forms of payment. At the same time, the increasingly competitive retail banking sector has witnessed the shift to transaction-based fees and charges, and the rationalisation of far-flung branch networks. As a result, uptake of the new access technology has been extremely rapid, prompted partly by its lower cost and convenience, but often by the lack of a branch substitute, particularly in rural, regional and outer suburban areas.

Controversy surrounds these changes, primarily from the viewpoint that consumers have suffered with the shifting emphasis of banks from net interest margin to net non-interest margin, especially when coupled with booming bank profits. From its standpoint, the Australian banking industry has been keen to dispel this criticism, arguing that '...banking in Australia has never been more affordable than it is today. Improved affordability has been most marked for household and small business customers, Australian bank fees and profits are not high by world standards, and everyday banking is cheaper than basic services such as water and transport' (Australian Bankers Association, 2003; 2004).

There is clearly some substance to this argument with net profits before tax and net interest and non-interest margins (as a ratio of total assets) of Australian banks at or below the OECD average and comparable to levels in the United Kingdom. The Reserve Bank of Australia has reached a similar conclusion (Reserve Bank of Australia, 2004). However, banks and the Australian Bankers' Association (2004) have also been careful to offer suggestions to consumers to cope with the greater than before emphasis on bank fees and charges: 
Use only branded ATMs of your bank (you pay fees for using other banks' ATMs); take cash out with any EFTPOS purchase and it counts as a single transaction; consolidate your accounts to save on monthly account fees; use telephone banking to obtain account information and do transactions; use BPAY to pay bills to over 6000 participating organisations; use fewer cheques (accounts with a cheque facility can attract government taxes on all withdrawals made from that account, and a fee for each cheque written after you have reached your account's fee-free transaction limit); view and print statements for free with Internet banking and print as many copies as you like, at no charge (over the counter copies are not usually free); use proprietary bank software on your computer to install a 'mini bank branch' and transfer funds, pay bills or check accounts online with the convenience that it is available 24 hours a day, 7 days a week, often with no start-up costs or access fees; check if your bank has a 'fee rebate system' for personal transaction and savings accounts that rewards people who bank electronically.

Publicity like this has met with limited success, with banks habitually criticised by media commentators, consumer groups, regulators and policymakers alike. For example, the Victorian Minister for Consumer Affairs recently called on the Federal Government to improve the transparency of bank fees and charges [notwithstanding an existing Australian Securities and Investments Commission guide on good disclosure of transaction banking fees], lamenting that the banks' behaviour in imposing new fees for internet banking was disappointing; 'Consumers need to know the cost of a transaction at the time they are making the transaction. This would give consumers the opportunity not to complete the transaction. Customers should also be given prior notice of any new fees so they can choose to switch banks if they wish' (Australian Securities and Investments Commission, 2002; Victorian Minister of Consumer Affairs, 2005).

Likewise, the Commonwealth Treasurer has called for banks to cut their account and transaction fees while encouraging consumers to find bank accounts that best suit their needs: 'I think a lot of people will be surprised by the level of fees that banks are charging and I would urge them to shop around' (Sydney Morning Herald, 2005). Lastly, the Australian Consumer Affairs (2001; 2002; 2005a; 2005b) has highlighted its ongoing concerns with the conduct of personal banking in Australia:

By 2000, transaction fees alone cost consumers about $\$ 430$ million a year, and that amount continues to increase. In 1993, the average cost of an over-the-counter transaction was 50 cents; by 2000 it was $\$ 2.38$. And banks are using increasingly complicated fee structures that make it very difficult to compare accounts. With such low interest [in everyday transaction accounts], account-keeping and transaction fees can quickly eat away at your money. You can easily end up paying much more in fees than you earn in interest.

Clearly, for better or worse, the emphasis lies on Australian consumers' awareness of the fees and charges applied to bank accounts, and their ability to make good choices regarding the choice of account in the first place, and then the most efficient and effective way of accessing this account.

Unfortunately, many consumers simply do not have the financial knowledge or skills to deal with such tasks. For example, the Australian Law Reform Commission's (2005) Seen and Heard report found that young people were ill informed about a wide range of consumer services, while the ANZ Bank's Survey of Adult Financial Literacy in Australia conducted by Roy Morgan Research (2003a; 2003b) showed that while most Australians have basic financial literacy, young consumers and those from low socioeconomic backgrounds were at a disadvantage in making informed decisions. Similarly, submissions to the Senate Select Committee on Superannuation and Financial Services (2000) concluded that 46 percent of Australians have 'unsatisfactorily low levels of literacy' and 15 percent are 'functionally illiterate'. Lastly, the Consumer and Financial Literacy Taskforce's (2004) Australian Consumers and Money stock take of initiatives by public, private and community sector bodies found that while there was no shortage of consumer information, a good proportion of that material was either not known, not properly targeted or not used by Australian consumers. This concern with financial 
literacy more broadly is clear both elsewhere in Australia and internationally (Schagen and Lines, 1996; US Department of Treasury, 2002; US Senate Committee on Banking, Housing and Urban Affairs, 2002; Braunstein and Welch, 2002; Hogarth, 2002; Consumer Bankers Association, 2003; Australian Securities and Investments Commission, 2005; Jumpstart Coalition for Personal Financial Literacy, 2005; Worthington, 2006b).

Putting this aside, some consumers, even if fully informed, have limited contact with lower-cost ways of accessing their transaction and savings accounts, and this restriction may limit their ability to properly manage personal banking fees and charges. Devlin (2005), for example, discusses the role of access exclusion - the restriction of access to financial services due to factors such as branch closures - as an element of financial exclusion in the UK. See also Financial Services Authority (2000a; 2000b). This also applies in Australia. Most recently, the Parliamentary Joint Committee on Corporations and Financial Services (2004) highlighted some of the problems with the newer substitutes for branch services:

Without doubt many benefits come with the use of electronic banking. The convenience, ease of access, and lower transaction costs attract more and more consumers. Not all Australians, however, are able to take advantage of the new technology and the technology itself has limitations in delivering branching services to regional, rural and remote Australia...including the absence of facilities such as ATMs, EFTPOS, computer terminals, even telephones in the community.

Accordingly, the purpose of this paper is to examine two important, and largely unresolved, aspects of this debate. First, establish the profile of consumers with entrée to the newer ways of accessing their transaction and savings accounts. This establishes a necessary, but not sufficient, condition for consumers properly managing the fees and charges on personal banking accounts in Australia. Second, quantify the level of knowledge of fees and charges in personal banking in Australia, and whether consumers are in a position to use this knowledge to make better decisions. The paper itself is divided into four main areas. The first section explains the empirical methodology and data employed in the analysis. The second section discusses variable specification, and the third section presents the results. The paper ends with some concluding remarks.

\section{Research method and data}

A convenient consumer behaviour model put forward by the Consumer and Financial Literacy Taskforce (2004) hypothesises that external events, socioeconomic background, personal characteristics, skill levels and choices of information all shape knowledge, perceptions, decisions and behaviour in financial services markets. First, economic, regulatory, cultural and political factors shape the external environment facing consumers. These comprise market forces regarding the price and non-price characteristics of products available, and non-market impacts such as government regulation concerning the information made available to consumers, including product disclosure, consumer protection and opportunities for redress. Second, the consumer's own socioeconomic and personal characteristics also affect their knowledge, perceptions and the decision-making process. These include education, age, gender, health status and cultural background along with needs and aspirations.

Third, there are the events that have happened in each consumer's life. In the context of financial services markets, these include past experiences (both good and bad) with particular products and services. Finally, there are things consumers can learn to assist financial consumption. These may include prerequisite skills (such as literacy and numeracy), planning skills (comprising budgeting, saving and spending), and risk management skills (including insurance and portfolio management). They may also include knowledge as to where information and 
advice may be obtained. Clearly, access to, knowledge of and behaviour towards personal banking may result from any or all of these sources, and so attempts to model their distribution should take into account the different demographic, socioeconomic and financial backgrounds of consumers.

The data used in this study is unpublished data from the ANZ Survey of Adult Financial Literacy in Australia: a national telephone survey of 3,548 respondents (Roy Morgan Research, 2003a; 2003b). The data is composed of three sets of information. The first set used in this study consists of each respondent's answers to a set of questions aimed at measuring access and understanding of personal bank accounts. The eight specific questions examined in this study are provided in the uppermost portion of Table 1 . The first four questions asked whether the respondent used or knew how to use ATMs, EFTPOS, telephone banking and internet banking for the purposes of personal banking: these questions address the issue of 'access'. All other things being equal, these ways of accessing bank accounts are more cost-effective in terms of fees and charges compared to branch banking, are information rich, available 24 hours a day, 7 days a week, minimise cash balances, optimise account balances for mortgage offset and interest-bearing accounts, and facilitate efficient and timely transfers and payments for goods and services. Table 1 includes the proportion of respondents who replied positively to these questions. Responses ranged between the 27.80 percent who used or knew how to use internet banking up to the 72.90 percent of respondent who knew how to use or used ATMs (unsurprisingly nearly all respondents knew how to use cash).

One major limitation that presents itself with this data is that the survey does not distinguish between respondents who 'used' and 'knew how to use' the various technologies. It is then possible that some consumers know how to use a particular technology, but choose not to because of some other reason. As a result, the proportion of the sample responding positively to the questions concerning access may overstate the proportion of the population that actually use the given technology. For example, consumers may not use internet banking, not because they do not know how, rather through a lack of access to an adequate internet connection through a standard phone line, digital subscriber line or broadband cable modem or some other strong preference or constraint. If the gap between the two is large a large number of policy interventions are possible that cannot be commented upon using the results of this analysis.

The second four questions assessed four aspects of respondents' ability to manage personal banking accounts. These included whether they didn't know fairly well, well or very well about the fees and charges that applied to their own bank account, didn't understood fairly well, well or very well their bank statements, whether they didn't shop around a little bit, a fair bit or a lot when arranging a new account and whether they hadn't visited and used an internet calculator sites to assist in the comparison of accounts on the basis of interest rates, fees and charges. These questions address 'awareness'. In general, respondents with a higher level of knowledge of bank accounts, who actively exploit the competitive banking market and make best use of the tools available to them, are better able to cost-effectively use their existing account and compare it with alternatives. Responses varied between the just 13.80 percent of respondents who didn't understand their bank statements at least fairly well and the 83.70 percent who hadn't used or visited an internet calculator site to compare the rates, fees and charges on bank accounts.

The analytical technique employed is to specify each respondent's responses concerning personal banking accounts as the dependent variable in a regression with demographic, socioeconomic and financial characteristics as predictors. The nature of the dependent variable (binomial) indicates discrete dependent 
variable techniques are appropriate. Accordingly, binary logit models are specified. The coding of the binary dependent variables is shown in Table 1 with separate regression equations specified for each of the eight responses.

\section{Specification of explanatory variables}

The next two sets of information are specified as explanatory variables in the binary logit regression models. The first relate to demographic and socioeconomic characteristics, and the second to financial characteristics. The first set of information is generally comparable to that employed in earlier studies of financial literacy, knowledge, perceptions and behaviour. The second set of information is used to identify financial characteristics as a means of establishing a connection between these and respondent characteristics beyond these factors.

The set of demographic and socioeconomic variables upon which the questions concerning personal bank accounts are regressed are first examined. The definition and coding of these variables is detailed in Table 1. Whilst there is no unequivocal rationale for predicting the direction and statistical significance of many of these independent variables, their inclusion is consistent with past studies of the determinants of financial access, literacy and behaviour (as variously and broadly defined) and the presumed interests of consumer groups, policymakers and other parties. For example, in studies of financial literacy Beal and Delpachitra (2003) included gender, household status, age, educational and employment status and time spent in the workforce, while Chen and Volpe (1998) added race and nationality, academic discipline and class rank. Most recently, Devlin (2005) specified educational attainment, employment status, housing tenure and ethnicity in a study of financial exclusion in the UK.

\section{$<$ TABLE 1 HERE $>$}

The first nine variables relate to the sex, geographical location, ethnic background and age of the respondent. These are used as proxies for characteristics exposing respondents to personal bank accounts including stage of life cycle, access to labour and credit markets, exposure to marketing and information campaigns, and language and computer skills. For example, Chen and Volpe's (1998) study of financial literacy concluded that '...the percentages of correct answers from the female participants (50.77\%) are lower than those from male participants (57.40\%)' as did Goldsmith and Goldsmith (1997). Similarly, Chen and Volpe (2002) concluded that the less (financially) knowledgeable group was also more likely to be younger and female, the Jumpstart Coalition for Personal Financial Literacy (2005) in the US established that Native, African, Hispanic and AsianAmericans scored lower than other (White) students and Devlin (2005) proved higher levels of financial exclusion for Afro-Caribbean and Asian consumers in the UK. Negative coefficients are hypothesised for gender, region and language with age coefficients being negative for younger and older respondents and positive for middle-aged respondents.

The next four variables indicate whether the respondent is non-working and looking for work (unemployed), non-working and a student, non-working and engaged in home duties, non-working and retired, and nonworking for any other reason. Garman et al. (1999), Beal and Delpachitra (2003), Worthington (2006b) and Devlin (2005) also included employment status. Possible reasons for differences in access and awareness of personal bank accounts for non-working respondents include lack of (work) access to computers, telephones and the internet, less exposure to work-related literacy campaigns, and fewer synergies between work-related 
knowledge and personal knowledge of banking. It is reasoned that all categories of non-working respondents will have lower levels of access and awareness regarding bank accounts: negative coefficients are hypothesised. Following this eleven categories of occupation are specified. It is generally argued that white collar occupations are associated with higher levels of financial knowledge. Positive coefficients are hypothesised for white collar occupations, especially those involving business management or ownership; negative coefficients for blue collar occupations, especially those in semi-skilled and unskilled trades.

The next four variables categorise respondents according to the highest level of education attained: namely, $4^{\text {th }}$ Form/Year 10 or lower (corresponding in most Australian states to eleven years of primary and secondary education and the first secondary education qualification), HSC/VCE/ $6^{\text {th }}$ Form/Year 12 (an additional two years of secondary education necessary for university matriculation), technical/commercial/TAFE certificate or diploma (vocational specific education following either of the above), and university/CAE degree (three-year programs equivalent to university, polytechnic or liberal arts college elsewhere). In the UK, Devlin (2005) categorised educational attainment as low (no formal qualifications), medium (CSE/GCSE/O Levels/City Guilds) or high (university degree). All other things being equal, mathematical and language literacy skills attained in secondary and tertiary education should be useful for the purposes of financial awareness about personal banking accounts, with higher levels of educational attainment associated with higher awareness. Positive coefficients are hypothesised.

The following two variables indicate whether the household structure is a single parent or a couple with children at home and follows suggestions that single parent household are at most risk through a lack of financial access and awareness (Devlin, 2005; Worthington, 2006a). Finally, the next three variables indicate whether the principal residence is owned outright, being bought or rented. This is similar to Devlin's (2005) categorisation of housing tenure as owner-occupied, private rented, local authority housing or housing association rented. Residential mortgages are the largest financial transaction entered into by nearly all Australian households, so that experience with dealing with such products may serve to improve access and awareness of bank accounts. A positive coefficient is hypothesised for respondents who own outright or are burying their own home.

The final four variables in Table 1 are quantitative variables for household income, investments and debt. Hogarth and O'Donnell (1999), Lee (2002) and Worthington (2006a; 2006b), for example, discuss some of the problems of low-to-moderate income households in accessing the mainstream financial sector. Access and awareness of bank accounts in this analysis is argued to increase with exposure to financial services markets. At the same time, the opportunity cost of any deficiency should increase as income and debt and investment increase, thereby providing an incentive for improving access and skills. By comparison, Chen and Volpe (1998) and Beal and Delpachitra (2003) specified income alone in their respective analyses of financial literacy. The financial variables are household income, household savings, household mortgage debt and household nonmortgage debt in thousands of Australian dollars. A positive coefficient is hypothesised when access and awareness about bank accounts is regressed against all four variables. It should be noted, however, that all welfare payments in Australia are transferred electronically and so even the neediest consumers have at least some familiarity with personal banking. This differs markedly to comparable experience elsewhere where the level of financial exclusion can be much higher, with many households without any mainstream financial services. For example, about nine percent of US households and seven percent of UK households do not have a transaction or savings account (Hogarth et al. 2000; Devlin, 2005). 


\section{Empirical findings}

The estimated coefficients and standard errors of the parameters for the binary logit regressions are provided in Tables 2 and 3. Also included in Tables 2 and 3 is the Nagelkerke $R^{2}$ as an analogue for $R^{2}$ in the linear regression model and the Hosmer-Lemeshow test for model misspecification. Table 2 presents the estimated coefficients, standard errors and significance for the models predicting technological access to bank accounts. Table 3 presents this information for the models predicting bank account awareness.

\section{<TABLE 2 HERE $>$}

Models employing the entire set of explanatory variables were initially estimated (not shown), followed by refined specifications (shown) obtained with forward stepwise regression using the Wald criteria. The refined models were always preferred in terms of the trade-off between comprehensiveness and complexity (given the lower value of the Hannan-Quinn criteria) so only the refined models are discussed. This allows a focus on the most significant factors affecting bank account access and awareness. The refined models also appear appropriate to the data examined and the values of the Nagelkerke $R^{2}$ are adequate. To test for multicollinearity, variance inflation factors (VIF) are calculated. As a rule of thumb, a VIF greater than ten indicates the presence of harmful collinearity. Amongst the independent variables, the highest VIFs are for age 30-39 (5.24), other white collar occupation (5.69), skilled trades occupation (4.98). This suggests that multicollinearity, while present, is not too much of a problem. The Hosmer-Lemeshow tests fail to reject the null hypotheses of no functional misspecification (that is, there is not a significant difference between the observed and predicted cell counts) so we may conclude that all eight models are appropriate for modelling access and awareness of personal banking accounts in Australia.

Start with the models predicting access in Table 2. For the ATM model (columns 2 and 3), the estimated coefficients (the coefficients reported are log odds, with the odds calculated as $e^{x}$ ) indicate that non-metropolitan, small business owners, farm workers, persons whose highest level of educational attainment is Year 10, households owning their home outright, and those with higher levels of non-mortgage debt have a greater likelihood of not accessing or being able to access their accounts by ATM.. Being in a non-metropolitan area decreases the odds of having ATM access by 1.44 times the estimated odds for a metropolitan respondent, 1.43 times the estimated odds for other occupations if a small business owner, and 3.93 times the estimated odds for those with other education levels for those respondents with Year 10 level only.

On the other hand, being aged 18-24, 30-39, 40-49, 50-59 and 60-69 increases the likelihood of having ATM access (odds of 8.28 times for the 18-24 year age group), as does being in home duties (odds of 1.49 times). Having a university education increases the odds of 1.63 times for university graduates over other levels of educational attainment. Clearly, with its high take-up rate (72.90\%) ATM access is a very common way of accessing bank accounts in general, but is disproportionately favoured by the young and highly-educated. The relatively lower access to ATMs of small business owners appears unusual, but shows that many small business owners conduct their personal banking when using branch services for their business banking and tend to favour cheque accounts.

The results of the model predicting EFTPOS access (columns 4 and 5) are similar in many respects. The main points of departure is that being female increases the odds of accessing EFTPOS by 1.34 times that compared to males, other white collar occupations by 1.23 times other occupations and 1.27 times for couples 
over singles. In contrast, telephone banking (columns 6 and 7) appears to have strong interrelationships with working life (in terms of access to free, on-hand phone services) and household asset and debt portfolios. For example, persons on home duties, retired and non-workers have less access to telephone banking (up to 2.90 times the odds of working respondents), professionals and other white collar workers have more (up to 1.43 times the odds for other occupations), as do those paying off their home (1.21 times for other forms of residence). The estimated coefficients on income, savings and mortgage debt are also positive and significant indicating telephone banking access increases non-linearly, but monotonically, with dollar value. Moreover, they also indicate that an increase in the dollar value of income increases the odds of access more than savings or mortgage debt.

At the other extreme there is internet banking (columns 8 and 9), which is arguably the most demanding (in terms of technical competence and hardware), with a corresponding lower take-up rate (just 27.80 percent of respondents). Unlike EFTPOS and telephone banking, females have significantly lower access to internet banking, as do the unemployed, the retired, non-workers, semi-professionals, skilled, semi-skilled and unskilled trades, and single parents. The most substantive factors influencing access to internet banking appear to be being aged 30-39 years (1.28 times the odds for other age groups) and being university educated (1.65 times the odds for other levels of educational attainment).

Table 3 includes the binary logit models predicting whether respondents don't know well, fairly well or very well about the fees and charges on their own bank account (columns 2 and 3), whether they don't shop around a little bit, a fair bit or a lot when arranging a new bank account (columns 4 and 5), don't understand their bank statements well, fairly well or very well (columns 6 and 7), and whether they hadn't used or visited internet calculator sites to compare bank accounts (columns 8 and 9). As before, models including the full set of explanatory variables were initially estimated, followed by forward stepwise regression models using the Wald criteria. In all instances, the refined models were preferred and only these are presented. In the case of a lack of awareness of fees and charges on their own bank account, nine variables were stepped into the model. These indicate that non-workers and persons with a Year 10 education are less likely to have a sound knowledge of bank account fees and charges, and that professional, small business owner, sales and other white collar occupations, couples and those with higher incomes and savings are more likely to have this knowledge. The highest positive likelihood for having such knowledge is for small business owners (1.59 times more the odds of other occupations) and the greatest negative likelihood is for non-workers (2.27 times less the odds of other respondents).

\section{$<$ TABLE 3 HERE $>$}

Once again there is some variation for the remaining three models. In sum, females are more likely to shop around for bank accounts, but less likely to use internet calculators than males (1.77 times respectively), the retired are less likely to shop around and understand their bank statements (1.63 time respectively) and renting households are more likely to shop around and less likely to understand their bank statements (1.29 times respectively). While the retired and renting households appear to lack in common the background and incentive to understand their bank statements, it is likely that retired household have established preferences for particular banks and products, while renting households are perhaps more concerned with finding bank accounts that accommodate the electronic rental payments in their fee-free transfers and facilitate the saving for a home loan deposit. Finally, internet calculator use appears to decrease strongly with age (18-24 year olds have 18.17 times 
the likelihood of visiting or using an internet calculator) and is closely linked with professional, sales and white collar occupations and the university educated.

As a final requirement, the ability of the models to accurately predict responses is examined. Table 4 provides the results for the models in Tables 2 and 3 with the predicted number in each response category. To start with, consider the predictions for the model of ATM access. Of the 2,585 respondents who indicated that they used or knew how to use ATMs, the estimated model correctly predicts 2,439 and incorrectly predicts 146 . With the 963 respondents who did not use or did not know how to use ATMs, the model correctly predicts 221 and incorrectly predicts 742. These represent the correct prediction of 94 percent of cases with ATM access and the correct prediction of 23 percent of cases without ATM access: a total prediction success of 75 percent of respondents. A good benchmark for these predictions is to compare them with the results of a (constant probability) model that would predict ATM access on the basis of its proportion in the sample.

In this respect, the ATM access model in this study has a 24 percent absolute improvement (in terms of correct predictions) and a 37 percent relative improvement (in terms of incorrect predictions) over the constant probability model. Similar results are obtained for the remaining three models predicting access to EFTPOS, telephone banking and internet banking with 76, 68 and 75 percent of respondents predicted correctly. By comparison, the models correctly predicted 76 percent of responses to the question concerning fees and charges, 61 percent for shopping around, 86 percent for understanding bank statements, and 85 percent for using internet calculators. Of course, these are 'in-sample' predictions and the results could differ if 'out-of-sample' data was made available.

The results of this analysis appear entirely consistent with recent evidence in the United States on banking access. Hogarth et al., (2004a) for example, posited that consumer acceptance and use of electronic banking technologies was related to the characteristics of both the individual consumer and the specific technology. They found that ' ....while the use of some products, particularly debit cards, has become more democratized over time, it is still the case that most e-banking products tend to be used by higher income, higher asset, younger, and better educated households'. Moreover, Hogarth et al. (2004b) also found that reasons for not have a particular form of access [in their instance, a checking account] can also be related to income, race/ethnicity, marital status/gender, planning horizon, education, previous account experience, and credit history. Clearly, there are any number of other parallels between the consumer banking experience in the United States and Australia [for example, internet banking participation was 28 percent in this study and 32 percent in the U.S. in 2003] (Hogarth et al. 2004a). This suggests that the findings in this study can be generalised to other economies, complementing work on bank access undertaken elsewhere. Unfortunately, and unlike Hogarth et al., as a cross-sectional analysis it is not possible for this study to comment on improvements in access and awareness over time, though this may be rectified with planned repeats of the ANZ Survey of Adult Financial Literacy.

\section{Concluding remarks and policy recommendations}

The present study uses binary logit models to investigate the role of demographic, socioeconomic and financial characteristics in determining access to and awareness of personal banking accounts in Australian adults. Access is defined in terms of the ability to use new technology comprising automated-teller machines (ATM), electronic funds transfer point of sale (EFTPOS), telephone banking and internet banking. Awareness is defined in terms of understanding bank statements and fee and charges, shopping around for accounts and the use of internet 
calculators to compare the interest rates, fees and charges on bank accounts. Together, these permit the proper management of personal banking benefits and costs.

In terms of access there appears to be a strong distinction between 'older' (well-adopted) ATM and EFTPOS technology and 'newer' (less-common) telephone and internet banking technology. For the former, usage is well spread across most consumers, though take-up rates clearly decrease with age. For example, a consumer aged 18-24 years is more than three times likelier to use EFTPOS than one aged 60-69 years. There also appears to be only a slight connection between income, debt and investments and these forms of access and little evidence of ethnic, occupational and gender bias. For the latter, however, consumers tend to be overwhelmingly male, professional and white-collar working households, with high levels of education and household assets. Just a few consumer groups appear to suffer disadvantage across all ways of accessing accounts, most notably nonmetropolitan households and those with only the lowest level of educational attainment.

In terms of awareness, most respondents appear to know the fees and charges that apply to their bank accounts, understand their bank statements and shop around for new accounts when the need arises. However, in common with the relatively low access to internet banking, only a small proportion has used internet-based calculators to assist them. Apart from this, fees and charges are generally less understood by non-workers, those with low levels of education and better understood by the professional, sales and white-collar occupied, couples those with higher incomes and savings. The retired, unskilled tradesmen and farm workers shop around less for new accounts, and bank statements are less understood by retirees, non-workers and renting households.

Two broad policy implications are noted. First, some target groups identified in the broader push for improving financial literacy in Australia - low-income, unemployed and non-working households - will be wellserved in terms of understanding and managing bank accounts if literacy programs by governments and businesses continue. However, some consumers - the young and women - who are frequently associated with low levels of literacy and interaction with sophisticated financial services, especially retirement planning and investment, do not appear to suffer the same disadvantage with basic banking services. The results also generally show that consumers with better access also have better awareness. It would appear, at least in Australia, that consumers develop the skills necessary for managing their bank accounts simultaneously with the new ways of access. If this had not been so, a far stronger case would exist for policy intervention and financial education.

Second, and rather more problematically, is the issue of access to bank accounts through the newer forms of technology. Clearly, some of these problems can also be addressed with education and training, but it also appears that supply-side factors also have a role to play. For example, the lower levels of access to banking accounts of rural and regional households may only ever be fully resolved through the better distribution of ATM and EFTPOS networks and the provision of low-cost telecommunication services. This is particularly problematic as these households are more disadvantaged by the recent contraction in branch services. Putting this aside, the historically high rate of technology take-up by Australians may eventually see telephone and internet banking become as commonplace as ATM and EFTPOS. In that event, most differences in access and awareness can be addressed through traditional literacy programs and measures.

\section{References}

Australian Bankers Association (2003) Bank fee figures in context. [WWW document]. URL http://www.bankers.asn.au/ Australian Bankers Association (2004) Affordability of banking. [WWW document]. URL http://www.bankers.asn.au/ Australian Consumers’ Association (2001) Bank fees can cost you a fortune. [WWW document]. URL http://www.choice.com.au/ 
Australian Consumers’ Association (2002) Banks bad and getting worse - 77\% of surveyed consumers think Federal government must act. [WWW document]. URL http://www.choice.com.au/

Australian Consumers’ Association (2005a) Soaring bank penalties hit consumers. [WWW document]. URL http://www.choice.com.au/

Australian Consumers' Association (2005b) End that bad bank marriage. [WWW document]. URL http://www.choice.com.au/

Australian Law Reform Commission (2005). Seen and heard. [WWW document]. URL http://www.austlii.edu.au/

Australian Securities and Investments Commission (2002) A guide to good disclosure of transaction banking fees. [WWW document]. URL http://www.asic.gov.au/

Australian Securities and Investments Commission (2005) Financial literacy in schools. [WWW document]. URL http://www.asic.gov.au/

Beal, D.J. \& Delpachtra, S.B. (2003) Financial literacy among Australian university students. Economic Papers, 22, 65-78.

Braunstein, S. \& Welch, C. (2002). Financial literacy: an overview of practice, research and policy. Federal Reserve Bulletin, November, 445-457.

Chen, H. \& Volpe, R. (1998) An analysis of personal financial literacy among college students, Financial Services Review, 7, $107-128$.

Chen, H. \& Volpe, R. (2002) Gender differences in personal financial literacy among college students. Financial Services Review, 11, 289-238.

Consumer and Financial Literacy Taskforce. (2004). Australian consumers and money, Commonwealth of Australia, Canberra.

Consumer Bankers Association. (2003). Survey on bank-sponsored financial literacy programs. [WWW document]. URL http://www.cbanet.org/

Devlin, J.F. (2005) A detailed study of financial exclusion in the UK. Journal of Consumer Policy, 28, 75-108.

Financial Services Authority (2000a) In or out? Financial exclusion: a literature and research review. [WWW document]. URL http://www.fsa.gov.uk/

Financial Services Authority (2000b) FSA publishes research on the causes and issues of financial exclusion. [WWW document]. URL http://www.fsa.gov.uk/

Garman, E.T., Kim, J., Kratzer, C.Y., Brunson, B.H. \& Joo, S.H. (1999) Workplace financial education improves personal financial wellness. Financial Counseling and Planning Journal, 10, 79-99.

Goldsmith, E. \& Goldsmith, R.E. (1997) Gender differences in perceived and real knowledge of financial investments. Psychological Report, 80, 236-238.

Hogarth, J. M. \& O’Donnell, K. H. (1999) Banking relationships of lower-income families and the governmental trend towards electronic payment. Federal Reserve Bulletin, 85, 459-473.

Hogarth, J. M. \& O’Donnell, K. H. (2000) If you build it, will they come? A simulation of financial product holdings among low-to-moderate income households. Journal of Consumer Policy, 23, 419-444.

Hogarth, J.M. (2002). Financial literacy and family and consumer sciences. Journal of Family and Consumer Sciences, 94, $15-28$.

Hogarth, J.M., Anguelov, C. \& Hilbert, M. (2004a) U.S. consumers and electronic banking, 1995 to 2003. Federal Reserve Bulletin, 90, 1-18.

Hogarth, J.M., Anguelov, C. \& Lee, J. (2004b) Why don't households have a checking account? Journal of Consumer Affairs, 38, 1-34.

Jumpstart Coalition for Personal Financial Literacy (2005) 2004 personal financial survey of high school seniors. [WWW document]. URL http://www.jumpstartcoalition.com/

Lee, J. (2002) The poor in the financial markets: Changes in the use of financial products, institutions and services from 1995 to 1998. Journal of Consumer Policy, 25, 203-231.

Parliamentary Joint Committee on Corporations and Financial Services (2004) Money Matters in the Bush: Inquiry into the Level of Banking and Financial Services in Rural, Regional and Remote Areas of Australia, Senate Printing Unit, Canberra.

Reserve Bank of Australia (2004) Banking fees in Australia. [WWW document]. URL http://www.rba.gov.au

Roy Morgan Research (2003a) ANZ Survey of Adult Financial Literacy in Australia: Final Report. ANZ Bank, Melbourne.

Roy Morgan Research. (2003b). ANZ Survey of Adult Financial Literacy in Australia: Stage 2: Telephone Survey Report. ANZ Bank, Melbourne.

Schagen, S. \& Lines, A. (1996) Financial Literacy in Adult Life: A Report to the Natwest Group Charitable Trust. National Foundation for Educational Research, Slough, Berkshire.

Senate Select Committee on Superannuation and Financial Services (2000) Roundtable on Choice of Superannuation Funds. Commonwealth of Australia, Canberra.

Sydney Morning Herald (2005) Costello shares concern over bank fees. [WWW document]. URL http://www.smh.com.au/

US Department of Treasury (2002) Treasury department announces office of financial education. [WWW document]. URL http://www.treas.gov/

US Senate Committee on Banking, Housing and Urban Affairs (2002) Hearings on the state of financial literacy and education in America. [WWW document]. URL http://www.frwebgate.access.gpo.gov/

Victorian Minister for Consumer Affairs (2005) Feds must act on unfair bank fees. [WWW document]. URL http://www.dpc.vic.gov.au/

Worthington, A.C. (2006a) Debt as a source of financial stress in Australian households. International Journal of Consumer Studies, 30, 2-15.

Worthington, A.C. (2006b) Predicting financial literacy in Australia. Financial Services Review, 15, 59-79. 
Personal bank account access and awareness in Australia $\cdot$ A.C. Worthington 
Table 1 Variable definitions and statistics

\begin{tabular}{|c|c|c|}
\hline Variable & Definition & Mean \\
\hline ATM & 1 if use or know how to use automated teller machines (ATM); 0 otherwise & 72.90 \\
\hline EFTPOS & 1 if use or know how to use electronic funds transfer point of sale (EFTPOS); 0 otherwise & 70.50 \\
\hline Telephone banking & 1 if use or know how to use telephone banking; 0 otherwise & 36.00 \\
\hline Internet banking & 1 if use or know how to use Internet banking; 0 otherwise & 27.80 \\
\hline Fees and charges & 1 if don't know fairly well, well or very well about the fees and charges that apply to own bank account; 0 otherwise & 24.20 \\
\hline Shop around & 1 if don't shop around a little bit, a fair bit or a lot when arranging a new ordinary or everyday account with a bank; 0 otherwise & 43.00 \\
\hline Understand accounts & 1 if don't understand bank statements fairly well, well or very well; 0 otherwise & 13.80 \\
\hline Internet calculators & 1 if haven't visited and used Internet calculator sites to compare interest rates, fees and charges on accounts; 0 otherwise & 83.70 \\
\hline Gender & 1 if female; 0 male & 50.56 \\
\hline Region & 1 if rural, regional or non-capital city household; 0 metropolitan & 37.80 \\
\hline Language & 1 if language spoken most often at home is non-English; 0 English & 10.01 \\
\hline Age 18-24 & 1 if aged $18-24$ years; 0 otherwise & 12.80 \\
\hline Age $25-29$ & 1 if aged $25-29$ years; 0 otherwise & 9.13 \\
\hline Age $30-39$ & 1 if aged $30-39$ years; 0 otherwise & 20.24 \\
\hline Age $40-49$ & 1 if aged $40-49$ years; 0 otherwise & 19.59 \\
\hline Age 50-59 & 1 if aged $50-59$ years; 0 otherwise & 15.39 \\
\hline Age $60-69$ & 1 if aged $60-69$ years; 0 otherwise & 11.92 \\
\hline Unemployed & 1 if non-working and looking for work (unemployed); 0 otherwise & 4.26 \\
\hline Student & 1 if non-working and principally engaged as student; 0 otherwise & 3.38 \\
\hline Home duties & 1 if non-working and principally engaged in home duties; 0 otherwise & 7.22 \\
\hline Retired & 1 if non-working and principally retired; 0 otherwise & 21.03 \\
\hline Non-worker & 1 if non-working and not student, home duties or retired; 0 otherwise & 2.37 \\
\hline Professional & 1 if principal occupation is professional; 0 otherwise & 11.02 \\
\hline Owners or executives & 1 if principal occupation is business owner or executive; 0 otherwise & 1.63 \\
\hline Small business owner & 1 if principal occupation is small business owner; 0 otherwise & 4.59 \\
\hline Sales & 1 if principal occupation is sales; 0 otherwise & 6.54 \\
\hline Semi-professional & 1 if principal occupation is semi-professional; 0 otherwise & 11.95 \\
\hline Other white collar & 1 if principal occupation is other white collar; 0 otherwise & 22.13 \\
\hline Skilled trades & 1 if principal occupation is skilled tradesman; 0 otherwise & 17.19 \\
\hline Semi-skilled trades & 1 if principal occupation is semi-skilled tradesman; 0 otherwise & 11.22 \\
\hline Unskilled trades & 1 if principal occupation is unskilled tradesman; 0 otherwise & 7.69 \\
\hline Farm owner & 1 if principal occupation is farm owner; 0 otherwise & 1.10 \\
\hline Farm worker & 1 if principal occupation is farm worker; 0 otherwise & 0.87 \\
\hline Year 10 & 1 if highest level of education is $4^{\text {th }}$ Form/Year 10 or lower; 0 otherwise & 28.27 \\
\hline Year 12 & 1 if highest level of education is $\mathrm{HSC} / \mathrm{VCE} / 6^{\text {th }}$ Form/Year $12 ; 0$ otherwise & 15.76 \\
\hline Technical & 1 if highest level of education completed is technical/commercial/TAFE; 0 otherwise & 9.67 \\
\hline University & 1 if highest level of education completed university/CAE; 0 otherwise & 25.48 \\
\hline Single parents & 1 if household structure is single parent with children at home; 0 otherwise & 6.85 \\
\hline Couples & 1 if household structure is couple with children at home; 0 otherwise & 36.27 \\
\hline Owned outright & 1 if residency is owned outright; 0 otherwise & 42.56 \\
\hline Paying off & 1 if residency is being paid off; 0 otherwise & 33.20 \\
\hline Rented & 1 if residency is being rented; 0 otherwise & 22.80 \\
\hline Income & Total household income $(\$ 000$ s) & 61.84 \\
\hline Savings & Total household savings incl. superannuation but excluding home value (\$000s) & 40.88 \\
\hline Mortgage debt & Total household mortgage debt (\$000s) & 52.75 \\
\hline Non-mortgage debt & Total household non-mortgage debt $(\$ 000 \mathrm{~s})$ & 15.38 \\
\hline
\end{tabular}


Table 2 Parameter estimates and statistics: Bank account access

\begin{tabular}{|c|c|c|c|c|c|c|c|c|}
\hline & \multicolumn{2}{|c|}{ ATM } & \multicolumn{2}{|c|}{ EFTPOS } & \multicolumn{2}{|c|}{ Telephone banking } & \multicolumn{2}{|c|}{ Internet banking } \\
\hline & $\begin{array}{l}\text { Estimated } \\
\text { coefficient }\end{array}$ & $\begin{array}{l}\text { Standard } \\
\text { error }\end{array}$ & $\begin{array}{l}\text { Estimated } \\
\text { coefficient }\end{array}$ & $\begin{array}{c}\text { Standard } \\
\text { error }\end{array}$ & $\begin{array}{l}\text { Estimated } \\
\text { coefficient }\end{array}$ & $\begin{array}{c}\text { Standard } \\
\text { error }\end{array}$ & $\begin{array}{l}\text { Estimated } \\
\text { coefficient }\end{array}$ & $\begin{array}{c}\text { Standard } \\
\text { error }\end{array}$ \\
\hline Constant & 0.004 & 0.141 & $-0.305^{\star \star}$ & 0.146 & $-1.688^{\star \star \star}$ & 0.159 & $-1.255^{\star \star \star}$ & 0.177 \\
\hline Gender & - & - & $0.289 * \star *$ & 0.082 & $0.331^{* * *}$ & 0.078 & $-0.317^{\star * *}$ & 0.086 \\
\hline Region & $-0.374^{\star \star \star}$ & 0.138 & $-0.423^{\star \star \star}$ & 0.135 & $-0.177^{\star \star}$ & 0.079 & - & - \\
\hline Age 18-24 & $2.114^{\star \star \star}$ & 0.189 & $2.243^{\star \star *}$ & 0.188 & - & - & - & - \\
\hline Age $25-29$ & $1.808^{\star \star \star}$ & 0.207 & $2.298^{\star * *}$ & 0.220 & $0.311^{\star \star}$ & 0.124 & - & - \\
\hline Age $30-39$ & $1.651^{\star \star \star}$ & 0.160 & $1.841^{\star * *}$ & 0.168 & - & - & $0.248^{\star *}$ & 0.100 \\
\hline Age $40-49$ & $1.352^{\star \star \star}$ & 0.148 & $1.556^{\star * *}$ & 0.157 & - & - & - & - \\
\hline Age $50-59$ & $0.963^{\star \star \star}$ & 0.142 & $1.101^{\star \star \star}$ & 0.145 & - & - & - & - \\
\hline Age $60-69$ & $0.677^{\star \star \star}$ & 0.145 & $0.668^{\star * *}$ & 0.147 & - & - & - & - \\
\hline Unemployed & - & - & - & - & - & - & $-0.529 \star \star$ & 0.231 \\
\hline Home duties & $0.400^{\star \star *}$ & 0.175 & - & - & $-0.442^{\star * *}$ & 0.154 & - & - \\
\hline Retired & - & - & - & - & $-0.652^{\star \star \star}$ & 0.115 & $-1.080^{\star \star \star}$ & 0.152 \\
\hline Non-worker & - & - & - & - & $-1.072^{\star \star \star}$ & 0.322 & $-1.288^{\star \star *}$ & 0.440 \\
\hline Professional & - & - & - & - & $0.305^{\star \star}$ & 0.127 & - & - \\
\hline Small business owner & $-0.357^{\star \star \star}$ & 0.176 & - & - & - & - & - & - \\
\hline Semi-professional & - & - & - & - & - & - & $-0.415^{\star \star \star}$ & 0.129 \\
\hline Other white collar & - & - & $0.211^{\star *}$ & 0.101 & $0.364^{\star \star *}$ & 0.090 & & \\
\hline Skilled trades & - & - & - & - & - & - & $-0.545^{\star \star \star}$ & 0.121 \\
\hline Semi-skilled trades & - & - & - & - & - & - & $-0.820^{\star \star \star}$ & 0.157 \\
\hline Unskilled trades & - & - & - & - & - & - & $-1.046^{\star \star \star}$ & 0.214 \\
\hline Farm worker & $-0.914^{\star \star \star}$ & 0.393 & - & - & - & - & - & - \\
\hline Year 10 & $-0.286^{\star \star *}$ & 0.094 & $-0.408^{\star \star \star}$ & 0.089 & $-0.360^{\star * *}$ & 0.096 & $-0.782^{\star \star \star}$ & 0.121 \\
\hline University & $0.495^{\star \star \star}$ & 0.110 & - & - & $0.223^{\star *}$ & 0.095 & $0.504^{\star \star \star}$ & 0.096 \\
\hline Single parents & - & - & - & - & - & - & $-0.490^{\star \star \star}$ & 0.184 \\
\hline Couples & - & - & $0.244^{\star \star}$ & 0.096 & $0.235^{\star \star \star}$ & 0.082 & - & - \\
\hline Owned outright & $-0.318^{\star \star \star}$ & 0.094 & $-0.499 \star \star \star$ & 0.093 & - & - & $-0.335^{\star \star \star}$ & 0.097 \\
\hline Paying off & - & - & - & - & $0.192^{* *}$ & 0.087 & - & - \\
\hline Income & - & - & - & - & $0.010^{\star \star \star}$ & 0.002 & $0.011^{\star \star \star}$ & 0.002 \\
\hline Savings & - & - & - & - & $0.005^{\star \star \star}$ & 0.002 & $0.005^{\star \star \star}$ & 0.002 \\
\hline Mortgage debt & - & - & - & - & $0.001^{* *}$ & 0.000 & $0.001^{\star * *}$ & 0.000 \\
\hline Non-mortgage debt & $-0.001^{\star \star *}$ & 0.001 & - & - & - & - & - & - \\
\hline Hosmer-Lemeshow & 5.746 & 0.676 & 8.533 & 0.383 & 6.072 & 0.639 & 7.913 & 0.442 \\
\hline Nagelkerke $\mathrm{R}^{2}$ & 0.172 & - & 0.226 & - & 0.138 & - & 0.249 & - \\
\hline
\end{tabular}

* $\mathrm{P} \leq 0.10$; $* * \mathrm{P} \leq 0.05 ; * \star * \mathrm{P} \leq 0.01$. Variables not present in any of the refined models have been removed from the table to save space. The null hypothesis for the Hosmer-Lemeshow test statistic is no functional misspecification. The Nagelkerke $\mathrm{R}^{2}$ is analogous to $\mathrm{R}^{2}$ in the linear regression model. 
Table 3 Parameter estimates and statistics: Bank account awareness

\begin{tabular}{|c|c|c|c|c|c|c|c|c|}
\hline & \multicolumn{2}{|c|}{ Fees and charges } & \multicolumn{2}{|c|}{ Shop around } & \multicolumn{2}{|c|}{ Understand accounts } & \multicolumn{2}{|c|}{ Internet calculators } \\
\hline & $\begin{array}{l}\text { Estimated } \\
\text { coefficient }\end{array}$ & $\begin{array}{c}\text { Standard } \\
\text { error }\end{array}$ & $\begin{array}{l}\text { Estimated } \\
\text { coefficient }\end{array}$ & $\begin{array}{c}\text { Standard } \\
\text { error }\end{array}$ & $\begin{array}{l}\text { Estimated } \\
\text { coefficient }\end{array}$ & $\begin{array}{c}\text { Standard } \\
\text { error }\end{array}$ & $\begin{array}{l}\text { Estimated } \\
\text { coefficient }\end{array}$ & $\begin{array}{c}\text { Standard } \\
\text { error }\end{array}$ \\
\hline Constant & $-0.579 * \star \star$ & 0.142 & $-0.124^{\star}$ & 0.074 & $-1.640 * \star \star$ & 0.158 & $6.198^{\star \star \star}$ & 0.619 \\
\hline Gender & - & - & $-0.205^{\star \star \star}$ & 0.070 & - & - & 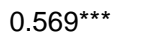 & 0.105 \\
\hline Age $18-24$ & - & - & - & - & - & - & $-2.900^{\star \star \star}$ & 0.605 \\
\hline Age $25-29$ & - & - & - & - & - & - & $-3.489 \star \star \star$ & 0.601 \\
\hline Age $30-39$ & - & - & - & - & - & - & $-3.521^{\star \star \star}$ & 0.594 \\
\hline Age $40-49$ & - & - & - & - & - & - & $-2.962^{\star \star \star}$ & 0.595 \\
\hline Age $50-59$ & - & - & - & - & - & - & $-2.365^{\star \star \star}$ & 0.601 \\
\hline Age $60-69$ & - & - & - & - & - & - & $-1.556^{\star \star}$ & 0.632 \\
\hline Retired & - & - & $0.693^{\star \star *}$ & 0.092 & $0.490^{* * *}$ & 0.118 & - & - \\
\hline Non-worker & $0.819^{\star \star \star}$ & 0.227 & $-0.320^{\star *}$ & 0.126 & $0.689^{\star \star \star *}$ & 0.266 & - & - \\
\hline Professional & $-0.445^{\star \star *}$ & 0.147 & - & - & $-0.692^{\star \star *}$ & 0.197 & $-1.059 * \star *$ & 0.166 \\
\hline Small business owner & $-0.462^{* *}$ & 0.208 & - & - & - & - & - & - \\
\hline Sales & $-0.340^{\star \star}$ & 0.170 & - & - & - & - & $-0.969 \star \star \star$ & 0.198 \\
\hline Semi-professional & - & - & - & - & - & - & $-0.660^{\star \star \star}$ & 0.169 \\
\hline Other white collar & $-0.353^{\star \star \star}$ & 0.103 & - & - & $-0.248^{\star \star}$ & 0.124 & $-0.944^{\star \star \star}$ & 0.135 \\
\hline Unskilled trades & - & - & $0.344^{\star \star \star}$ & 0.130 & - & - & - & - \\
\hline Farm worker & - & - & $0.767^{\star \star}$ & 0.383 & - & - & - & - \\
\hline Year 10 & $0.369 * \star *$ & 0.088 & - & - & - & - & $0.614^{\star \star *}$ & 0.162 \\
\hline University & - & - & $-0.318^{\star \star \star}$ & 0.088 & - & - & $-0.321^{\star \star \star}$ & 0.122 \\
\hline Couples & $-0.204^{\star \star}$ & 0.085 & $-0.231^{\star \star \star}$ & 0.078 & - & - & - & - \\
\hline Paying off & - & - & - & - & - & - & $-0.257^{\star \star}$ & 0.112 \\
\hline Rented & - & - & $-0.194 * \star$ & 0.087 & $0.275^{\star \star}$ & 0.115 & - & - \\
\hline Income & $-0.004^{* *}$ & 0.002 & - & - & $-0.005^{\star \star}$ & 0.002 & $-0.013^{\star \star *}$ & 0.002 \\
\hline Savings & $-0.005^{\star \star \star}$ & 0.002 & - & - & - & - & -0.009 & 0.002 \\
\hline Mortgage debt & - & - & - & - & - & - & $-0.001^{\star \star}$ & 0.000 \\
\hline Hosmer-Lemeshow & 5.252 & 0.730 & 3.637 & 0.888 & 8.277 & 0.407 & 4.179 & 0.841 \\
\hline Nagelkerke $\mathrm{R}^{2}$ & 0.042 & - & 0.059 & - & 0.028 & - & 0.266 & - \\
\hline
\end{tabular}

${ }^{*} \mathrm{P} \leq 0.10 ;{ }^{* *} \mathrm{P} \leq 0.05 ;{ }^{* *} \mathrm{P} \leq 0.01$. Variables not present in any of the refined models have been removed from the table to save space. The null hypothesis for the Hosmer-Lemeshow test statistic is no functional misspecification. The Nagelkerke $R^{2}$ is analogous to $\mathrm{R}^{2}$ in the linear regression model. 
Table 4 Observed and predicted values

\begin{tabular}{|c|c|c|c|c|c|c|}
\hline & & \multicolumn{2}{|c|}{ Observed response } & \multicolumn{2}{|c|}{ Predicted response } & \multirow{2}{*}{$\begin{array}{r}\text { Correc } \\
\% \\
\end{array}$} \\
\hline & & No & Yes & No & Yes & \\
\hline \multirow{3}{*}{ ATM } & No & 963 & 0 & 221 & 742 & 23 \\
\hline & Yes & 0 & 2585 & 146 & 2439 & 94 \\
\hline & Total & 963 & 2585 & 367 & 3181 & 75 \\
\hline \multirow{3}{*}{ EFTPOS } & No & 1045 & 0 & 438 & 607 & 42 \\
\hline & Yes & 0 & 2503 & 254 & 2249 & 90 \\
\hline & Total & 1045 & 2503 & 692 & 2856 & 76 \\
\hline \multirow{3}{*}{$\begin{array}{l}\text { Telephone } \\
\text { banking }\end{array}$} & No & 2269 & 0 & 1973 & 296 & 87 \\
\hline & Yes & 0 & 1679 & 850 & 429 & 26 \\
\hline & Total & 2269 & 1679 & 2823 & 725 & 68 \\
\hline \multirow{3}{*}{$\begin{array}{l}\text { Internet } \\
\text { banking }\end{array}$} & No & 2563 & 0 & 2343 & 220 & 91 \\
\hline & Yes & 0 & 985 & 668 & 317 & 32 \\
\hline & Total & 2563 & 985 & 3011 & 537 & 75 \\
\hline \multirow{3}{*}{$\begin{array}{l}\text { Fees and } \\
\text { charges }\end{array}$} & No & 2688 & 0 & 2672 & 16 & 99 \\
\hline & Yes & 0 & 860 & 843 & 17 & 2 \\
\hline & Total & 2688 & 860 & 3515 & 33 & 76 \\
\hline \multirow{3}{*}{ Shop around } & No & 2024 & 0 & 1696 & 328 & 84 \\
\hline & Yes & 0 & 1524 & 1052 & 472 & 31 \\
\hline & Total & 2024 & 1524 & 2748 & 800 & 61 \\
\hline \multirow{3}{*}{$\begin{array}{l}\text { Understand } \\
\text { accounts }\end{array}$} & No & 3059 & 0 & 3059 & 0 & 100 \\
\hline & Yes & 0 & 489 & 489 & 0 & 0 \\
\hline & Total & 3059 & 489 & 3548 & 0 & 86 \\
\hline \multirow{3}{*}{$\begin{array}{l}\text { Internet } \\
\text { calculators }\end{array}$} & No & 578 & 0 & 95 & 483 & 16 \\
\hline & Yes & 0 & 2970 & 60 & 2910 & 98 \\
\hline & Total & 578 & 2970 & 155 & 3393 & 85 \\
\hline
\end{tabular}

Observed is the actual response by category, predicted is the predicted response by category; percentage corrected is predicted response by category as a percentage of the observed category; the predictions correspond to the refined models in Tables 2 and 3; total percentage correct is the number of correct predictions as a percentage of the total observed. 